\title{
Abattoir Based Survey of Bovine Cystic Echinococcosis in Selected Commercial Abattoir in Ethiopia
}

\author{
Adem Hiko $^{1^{*}}$, Hassen Ibrahim ${ }^{1}$ and Getahun E Agga ${ }^{2}$ \\ ${ }^{1}$ Department of Veterinary Epidemiology, Microbiology and Public Health, College of Veterinary Medicine, Haramaya University, Haramaya, Ethiopia \\ ${ }^{2}$ US Department of Agriculture, Roman L Hruska US Meat Animal Research Center, Agricultural Research Service, Clay Center, Nebraska, USA
}

*Corresponding author: Adem Hiko, Department of Veterinary Epidemiology, Microbiology and Public Health, College of Veterinary Medicine, Haramaya University, Haramaya, Ethiopia, Tel: +251 940240080; E-mail: adex.2010ph@gmail.com

Rec date: February 28, 2018; Acc date: March 22, 2018; Pub date: March 23, 2018

Copyright: @ 2018 Hiko A, et al. This is an open-access article distributed under the terms of the Creative Commons Attribution License, which permits unrestricted use, distribution, and reproduction in any medium, provided the original author and source are credited.

\begin{abstract}
Hydatidosis is a widespread parasitic disease posing a significant public health and economic burden in developing countries. Abattoir survey was conducted to determine the prevalence of cystic echinococcosis (CE) in cattle, its organ distribution and to estimate financial loss due to organ condemnation. A total of 662 cattle originated from four different areas Ethiopia were examined during routine meat inspection. Bovine CE was observed in more than a half $(51 \%)$ of all cattle studied. The prevalence of CE was significantly associated with the origin of the cattle and study month. Area specific prevalences were 44\% ( $n=386)$ in Arsi, 30\% ( $n=91)$ in Borana, 85\% ( $n=80)$ in Jimma and $67 \%(n=105)$ in Mi'eso. The lowest prevalence $(32 \%)$ was observed in February and the highest prevalence $(75 \%)$ was observed in December. Of the animals positive for hydatid cyst $(n=335)$, in $70 \%$ of them had cysts were found in the lungs followed by the liver (30\%). Out of 386 multiple cysts observed $74 \%(285 / 386)$ of them were fertile and the remaining $26 \%(101 / 386)$ were calcified cysts. Bovine CE was estimated to cause a total financial loss of 3,353.77 US $\$$ annually due to organ condemnation. The high prevalence of cystic echinococcosis observed warrants the need for appropriate control measures to reduce the public health and economic impacts of the disease.
\end{abstract}

Keywords: Cystic echinococcosis; Hydatid cyst; Hydatidosis; Cattle

\section{Introduction}

Cystic echinococcosis (CE), also known as hydatidosis, is a zoonotic parasitic disease caused by the metacestodes (larval stages) of the tapeworm Echinococcus granulosus [1]. It is one of the tropical neglected diseases with a major public health concern widely distributed throughout the world [2,3]. Cystic echinococcosis is an economically important disease because of the high medical cost to treat human infections and through condemnation of edible organs in food animals [4]. Dogs and foxes are the primary definitive hosts for the adult parasite while numerous herbivorous animals act as intermediate hosts for the larval stages [5]. Humans are accidental hosts [5]. The intermediate hosts are infected through ingestion of the eggs while the definitive hosts are infected through ingestion of metacestode larvae from the tissues of the intermediate hosts. In the intermediate hosts, the majority of the hydatid cysts develop in the liver and lungs and to a lesser extent in the spleen, kidneys and heart $[2,5]$.

In Ethiopia, the occurrence of $\mathrm{CE}$ has been reported from dogs, $[6,7]$ cattle, [8-16] sheep and goats [6,17] and humans [18-20]. Additional surveys are required to estimate the burden of the disease in humans, and to provide information needed for national control strategies. Slaughter houses provide valuable information on the prevalence of hydatidosis and also play a significant role in the control of the disease by breaking its lifecycle. The occurrences and financial significance of bovine cystic echincoccosis in has also been reported from northern Ethiopia [21]. Therefore the objective of this study was to determine the prevalence and organ distribution of CE in cattle originated from different parts of Ethiopia using abattoir survey.

\section{Materials and Methods}

The present study was conducted at a commercial abattoir located in Bishoftu, Ethiopia. A total of 662 heads of cattle were randomly selected during ante-mortem examination. The study animals were identified by origin. The study cattle were originated from Arsi $(n=386)$, Borana $(n=91)$, Jimma $(n=80)$ and Mieso $(n=105)$ areas of Oromia Regional State. Routine meat inspection was used for the detection of hydatid cysts in the liver, lungs, heart and kidneys. Logistic regression was used to analyze the effect of animal origin and study month on the prevalence of hydatidosis. The annual financial loss attributed to organ condemnation due to hydatidosis was calculated according to the method used by Ogunrinade and Ogunrinade [22]. The annual number of cattle slaughtered at the abattoir was 1400 and the price of cattle offal in the export market was estimated at 1 US dollar/kg based on the information obtained from the abattoir. Bonferroni adjustments were made for multiple comparisons and $\mathrm{P}<0.05$ was considered significant. Data were analyzed with STATA 13 (StataCorp LP, College Station, Texas).

\section{Results}

Out of 662 animals examined, 335 (51\%) were positive for hydatidosis, of which $44 \%, 30 \%, 85 \%$ and $67 \%$ were observed in cattle originated from Arsi, Borana, Jimma and Mieso respectively (Table 1). There was a significant variation in the prevalence of hydatidosis by the origin of the animals (Figure 1). As shown in Table 1, the highest 
Citation: Hiko A, Ibrahim H, Agga GE (2018) Abattoir Based Survey of Bovine Cystic Echinococcosis in Selected Commercial Abattoir in

Page 2 of 5

proportion of hydatid cysts were observed in the lungs $(36 \% ; n=662)$ followed by liver $(15 \% ; n=662)$.

\begin{tabular}{|l|l|l|l|l|l|l|}
\hline \multirow{2}{*}{ Origin } & \multirow{2}{*}{$\begin{array}{l}\text { No of } \\
\text { animals } \\
\text { examined }\end{array}$} & \multicolumn{5}{|c|}{ No. (\%) positive(a) } \\
\cline { 5 - 7 } & Liver & Lung & Heart & Kidney & Total \\
\hline Arsi & 386 & $47(12)$ & $118(31)$ & $2(0.5)$ & $0(0)$ & $170(44)$ \\
\hline Borana & 91 & $8(9)$ & $7(8)$ & $0(0)$ & $0(0)$ & $27(30)$ \\
\hline Jimma & 80 & $10(13)$ & $55(69)$ & $0(0)$ & $4(5)$ & $68(85)$ \\
\hline Mi'eso & 105 & $35(33)$ & $56(53)$ & $0(0)$ & $0(0)$ & $70(67)$ \\
\hline Total & 662 & $100(15)$ & $236(36)$ & $2(0.3)$ & $4(0.6)$ & $335(51)$ \\
\hline
\end{tabular}

Table 1: Number of animals studied and the distribution of cystic echinococcosis in different organs by animal origin. a) Proportions were calculated from the number of animals indicated in each row.

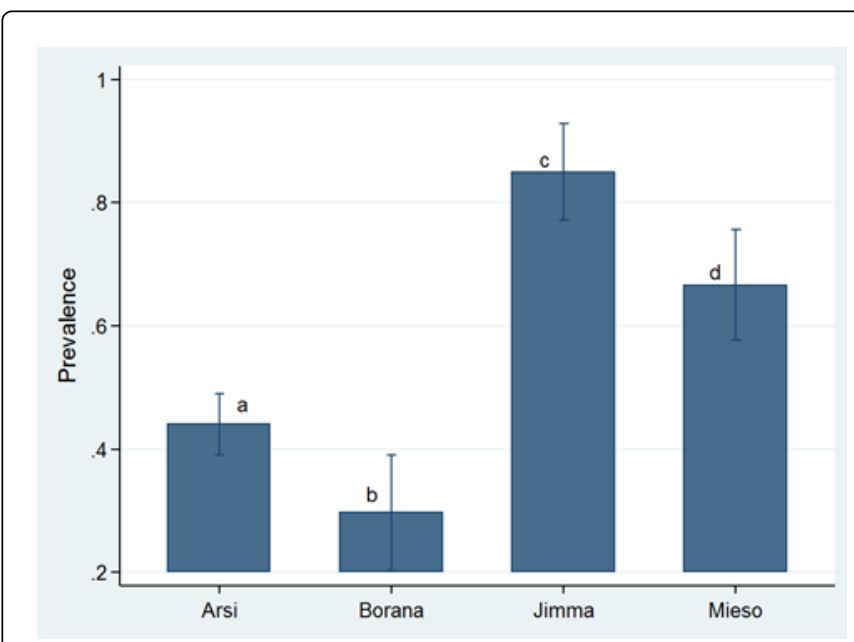

Figure 1: Model adjusted prevalence of bovine cystic echinococcosis by cattle source.

Of the animals with at least one organ positive for hydatid cyst, $70 \%$ $(n=335)$ were found in the lungs followed by the liver $(30 \%)$. There were statistically significant differences between the study months (Figure 2). The highest (75\%) and the lowest (32\%) monthly prevalences were recorded during December and February respectively (Table 2).

\begin{tabular}{|l|l|l|l|l|l|l|}
\hline \multirow{2}{*}{ Month } & \multirow{2}{*}{$\begin{array}{l}\text { No. } \\
\text { examined }\end{array}$} & \multicolumn{5}{|c|}{ No (\%) positive(a) } \\
\cline { 3 - 7 } & Liver & Lung & Heart & Kidney & Total \\
\hline November & 153 & $22(14.4)$ & $48(31.4)$ & $0(0)$ & $0(0)$ & $\begin{array}{l}72 \\
(47)\end{array}$ \\
\hline December & 160 & $52(32.5)$ & $94(58.8)$ & $2(1.3)$ & $0(0)$ & $\begin{array}{l}120 \\
(75)\end{array}$ \\
\hline January & 171 & $11(6.4)$ & $64(37.4)$ & $0(0)$ & $4(2.3)$ & $\begin{array}{l}87 \\
(51)\end{array}$ \\
\hline February & 178 & $15(8.4)$ & $30(16.9)$ & $0(0)$ & $0(0)$ & $\begin{array}{l}56 \\
(31.5)\end{array}$ \\
\hline
\end{tabular}

\begin{tabular}{|l|l|l|l|l|l|l|}
\hline Total & 662 & $100(15)$ & $\begin{array}{l}236 \\
(35.7)\end{array}$ & $2(0.3)$ & $4(0.6)$ & $\begin{array}{l}335 \\
(51)\end{array}$ \\
\hline
\end{tabular}

Table 2: Monthly prevalence of cystic echinococcosis in cattle examined at a slaughter house in Ethiopia. a) Proportions were calculated from the number of animals indicated in each row.

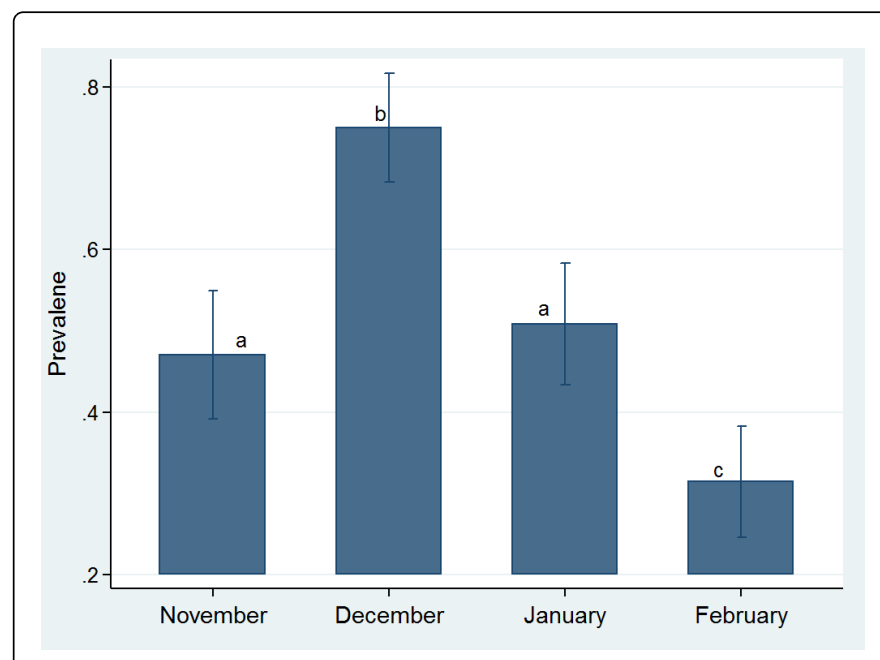

Figure 2: Monthly prevalence of cystic echinococcosis in slaughter cattle in Ethiopia.

As shown in Table 3, out of 662 examined cattle, a total 285 (43.05\%) and 101 (15.26\%) were found harboring fertile and calcified CE, respectively. Significant differences were observed among the cattle origin and study months both for the proportion of fertile and calcified cysts observed. We note that cattle examined in the month of December had the highest fertile cysts than the other study months.

\begin{tabular}{|l|l|l|l|l|l|l|l|}
\hline \multicolumn{2}{|c|}{ Positive by animal origin } & \multicolumn{3}{c|}{ Monthly positive } \\
\hline $\begin{array}{l}\text { Anim } \\
\text { al } \\
\text { Origin } \\
\text { Orin }\end{array}$ & $\begin{array}{l}\text { No. } \\
\text { d }\end{array}$ & $\begin{array}{l}\text { Fertil } \\
\text { e } \\
\text { cyst } \\
\text { No. } \\
(\%)\end{array}$ & $\begin{array}{l}\text { Calcifie } \\
\text { d cyst } \\
\text { No. (\%) }\end{array}$ & Month & $\begin{array}{l}\text { No. } \\
\text { examine } \\
\text { d }\end{array}$ & $\begin{array}{l}\text { Fertile } \\
\text { cyst } \\
\text { No. } \\
(\%)\end{array}$ & $\begin{array}{l}\text { Calcifie } \\
\text { d cyst } \\
\text { No. (\%) }\end{array}$ \\
\hline Arsi & 386 & $\begin{array}{l}145 \\
(37.6)\end{array}$ & $38(9.8)$ & $\begin{array}{l}\text { Novembe } \\
\text { r }\end{array}$ & 153 & $\begin{array}{l}57(37 . \\
3)\end{array}$ & $\begin{array}{l}18 \\
(18.8)\end{array}$ \\
\hline $\begin{array}{l}\text { Boran } \\
\text { a }\end{array}$ & 91 & $\begin{array}{l}15 \\
(16.5)\end{array}$ & $\begin{array}{l}14 \\
(15.4)\end{array}$ & $\begin{array}{l}\text { Decembe } \\
\text { r }\end{array}$ & 160 & $\begin{array}{l}118 \\
(73.8)\end{array}$ & $9(5.6)$ \\
\hline Jimma & 80 & $\begin{array}{l}57 \\
(71.3)\end{array}$ & $\begin{array}{l}45 \\
(56.3)\end{array}$ & January & 171 & $\begin{array}{l}67 \\
(39.2)\end{array}$ & $\begin{array}{l}56 \\
(32.8)\end{array}$ \\
\hline Mi'eso & 105 & $\begin{array}{l}68 \\
(64.8)\end{array}$ & $4(3.8)$ & February & 178 & $\begin{array}{l}43 \\
(24.2)\end{array}$ & $\begin{array}{l}18 \\
(10.1)\end{array}$ \\
\hline Total & 662 & $\begin{array}{l}285 \\
(43.1)\end{array}$ & $\begin{array}{l}101 \\
(15.3)\end{array}$ & Total & 662 & $\begin{array}{l}285 \\
(43.1)\end{array}$ & $\begin{array}{l}101 \\
(15.3)\end{array}$ \\
\hline & $x 2$ & 77.07 & 123.36 & & $X 2$ & 90.66 & 123.37 \\
\hline
\end{tabular}




\begin{tabular}{|c|c|c|c|c|c|}
\hline$P$-value & $\begin{array}{l}<0.00 \\
1\end{array}$ & $<0.001$ & $P$-value & $<0.001$ & $<0.001$ \\
\hline
\end{tabular}

Table 3: Prevalence of fertile and calcified cystic echinococcosis by cattle origin and study month.

The distribution of fertile and calcified cysts in the four targeted internal organs (liver, lung, heart and kidneys) is shown in Table 4 stratified by cattle origin and study month. The prevalence of fertile cysts in the lever, lungs and kidneys significantly $(\mathrm{P}<0.01)$ differ among the cattle origin with no difference in the heart. The prevalence of calcified cysts in the lever, lungs and heart significantly $(\mathrm{P}<0.01)$ differ among the cattle origin with no difference in the kidneys. The distribution of fertile and calcified cysts in the various organs also differed by the study month.

\begin{tabular}{|c|c|c|c|c|c|c|c|c|c|}
\hline \multirow[b]{2}{*}{ Origin and month } & \multirow{2}{*}{$\begin{array}{ll}\begin{array}{l}\text { Total } \\
\text { examined }\end{array} & \text { no. }\end{array}$} & \multicolumn{4}{|c|}{ Fertile CE in organs no. (\%) } & \multicolumn{4}{|c|}{ Calcified CE in organs no. (\%) } \\
\hline & & Liver & Lung & Heart & Kidney & Liver & Lung & Heart & Kidney \\
\hline Arsi & 386 & $47(12.2)$ & $118(30.6)$ & $2(0.5)$ & $0(0.0)$ & $36(9.3)$ & $0(0.0)$ & $0(0.0)$ & $2(0.5)$ \\
\hline Borana & 91 & $8(8.8)$ & $7(7.7)$ & $0(0.0)$ & $0(0.0)$ & $14(15.4)$ & $0(0.0)$ & $0(0.0)$ & $0(0.0)$ \\
\hline Jimma & 80 & $10(12.5)$ & $55(68.8)$ & $0(0.0)$ & $4(5.0)$ & $41(51.3)$ & $0(0.0)$ & $14(17.5)$ & $0(0.0)$ \\
\hline Mi'eso & 105 & $35(33.3)$ & $56(53.3)$ & $0(0.0)$ & $0(0.0)$ & $0(0.0)$ & $4(3.5)$ & $0(0.0)$ & $0(0.0)$ \\
\hline$x^{2}$ & & 33 & 87.8 & 1.4 & 29.27 & 118.2 & 21.35 & 104.05 & 1.4 \\
\hline P-value & & $<0.01$ & $<0.01$ & 0.69 & $<0.01$ & $<0.001$ & $<0.001$ & $<0.001$ & 0.697 \\
\hline November & 153 & $22(14.4)$ & $48(31.4)$ & $0(0.0)$ & $0(0.0)$ & $14(9.2)$ & $4(2.6)$ & $0(0.0)$ & $0(0.0)$ \\
\hline December & 160 & $52(32.5)$ & $94(58.8)$ & $2(1.3)$ & $0(0.0)$ & $7(4.4)$ & $0(0.0)$ & $0(0.0)$ & $2(1.3)$ \\
\hline January & 171 & $11(6.4)$ & $64(37.4)$ & $0(0.0)$ & $4(2.3)$ & $52(30.4)$ & $0(0.0)$ & $14(8.2)$ & $0(0.0)$ \\
\hline February & 178 & $15(8.4)$ & 30 (16.9) & $0(0.0)$ & $0(0.0)$ & $18(10.1)$ & $0(0.0)$ & $0(0.0)$ & $0(0.0)$ \\
\hline$x^{2}$ & & 53.03 & 66.08 & 6.29 & 11.55 & 56.6 & 13.38 & 104.05 & 6.29 \\
\hline P-value & & $<0.01$ & $<0.01$ & 0.098 & 0.009 & $<0.001$ & 0.004 & $<0.001$ & 0.098 \\
\hline Total & 662 & $100(15.1)$ & $236(35.7)$ & $2(0.3)$ & $4(0.6)$ & $91(13.8)$ & $4(0.6)$ & $14(2.1)$ & $2(0.5)$ \\
\hline
\end{tabular}

Table 4: Distribution of cystic echinococcosis in the internal organs of slaughter cattle $(n=662)$ by animal origin and month of study.

As shown in Table 5, the annual monitory losses from organs rejection as a result of hydatidosis were estimated to be 3,353.77 US\$ from export and 19,877.2 in Ethiopian currency from local markets.

\begin{tabular}{|c|c|c|c|c|c|c|}
\hline \multirow{2}{*}{$\begin{array}{l}\text { Organ } \\
\text { examined }\end{array}$} & \multirow{2}{*}{$\begin{array}{l}\text { Rejection } \\
\text { rate (\%) }\end{array}$} & \multirow{2}{*}{$\begin{array}{l}\text { Annual } \\
\text { slaughter } \\
\text { (no.) }\end{array}$} & \multicolumn{2}{|c|}{$\begin{array}{l}\text { Average market } \\
\text { price }\end{array}$} & \multicolumn{2}{|c|}{ Loss per organ } \\
\hline & & & $\begin{array}{l}\text { Export } \\
\text { (US\$) }\end{array}$ & $\begin{array}{l}\text { Local } \\
\text { (ETB) }\end{array}$ & $\begin{array}{l}\text { Export } \\
\text { (US\$) }\end{array}$ & $\begin{array}{l}\text { Local } \\
\text { (ETB) }\end{array}$ \\
\hline Liver & 28.7 & 1400 & 5 & 32 & 2,009 & 12857.6 \\
\hline Lung & 36.25 & 1400 & 2.5 & 12 & $1,268.75$ & 6090 \\
\hline Heart & 2.42 & 1400 & 1.5 & 20 & 50.82 & 677.6 \\
\hline Kidney & 0.9 & 1400 & 2 & 20 & 25.2 & 252 \\
\hline \multicolumn{5}{|c|}{ Total loss to the abattoir per year } & $3,353.77$ & $19,877.2$ \\
\hline
\end{tabular}

Table 5: Estimated annual economic losses from organs condemnation due to hydatidosis.

\section{Discussion}

The aim of the present study was to investigate the prevalence of bovine cystic echinococcosis (CE), its organ distribution and estimated financial loss due to organ condemnation at a commercial abattoir in Ethiopia. The present study indicated the widespread occurrence of the disease in cattle among the four cattle origins (Arsi, Borana, Jimma and Mieso). Various previously reported abattoir based surveys have indicated the presence of bovine $\mathrm{CE}$ in the northern $[7,9,10,12,13,18,21,23]$, central $[7,17,24]$, southern $[8,11,14,15]$ and western Ethiopia [16] indicating the widespread and endemic occurrence of animal echinococcosis throughout the country. This widespread occurrence could be attributed to high population of stray dogs and their easy access to the offal of slaughtered animals. Backyard slaughter of animals is a widespread practice in Ethiopia in which any condemned offal is given to dogs. These two factors (presence of stray dogs and backyard slaughter practice) play a significant role in the epidemiology of hydatidosis [3].

Hydatidosis is a significant zoonosis warranting for control measures in endemic countries such as Ethiopia. Such control measures should focus on enforcing food safety measures such as availability of slaughterhouses in the rural parts of the country, proper offal disposal and public education [3]. Reports on human hydatidosis in Ethiopia are limited [18-20] and as such the public health impacts of the disease could be underreported. A retrospective study [18] has reported a complete lack of awareness of the general public about hydatidosis in Ethiopia indicating the need for public education. Hydatidosis is one of the zoonotic diseases in which "one health" 
approach can be applied for its control. Collaboration between medical and veterinary medicine is needed to prevent and control human hydatidosis.

Significant variation in the prevalence of $\mathrm{CE}$ among the sources of the study cattle was observed in the present study. This variation could be explained by underlying differences in the ecology and animal production system that affect the life cycle of the parasite. Studies have shown that temperature has a significant effect on the survival of echinococcus eggs in which eggs survive longer under cooler temperatures than semi-arid condition [25]. In the present study, the lowest prevalence $(30 \%)$ was observed in Borana zone. Borana is characterized by arid climate with average annual rain fall of $58 \mathrm{~mm}$ and frequent drought [26]. On the other hand, the highest prevalence $(85 \%)$ was detected in cattle originated from Jimma zone which is characterized by high humidity and plenty of rainfall. Another important factor is the difference in the livestock production system. Livestock production system in Borana is pastoral production system in which livestock seasonally move from place to place in search of pasture and water. This seasonal movement of cattle from residential areas can limit the contact between dogs and animals. On the other hand, the livestock production system in Arsi, Jimma and Mieso is sedentary and it is characterized by mixed agriculture-both animal and crop production. There is high livestock-dog contact which can enhance the spread of the parasite.

We found higher prevalence of cysts in the lungs and liver than in the heart or kidneys. In general, lungs and liver are found to be the major organs infected with $\mathrm{CE}$ and condemned offal's because of the presence of large capillaries to provide nutrients for the blood borne onchospheres, and also they provide spaces for the developments of the cyst. Similar suggestions were given [3,21]. It is major causes for lung condemnation. Moreover, the present higher number of animal being harbor cyst in both lung and liver also show theses organs are suitable for the development of CE.

The monthly variation in the prevalence of bovine $\mathrm{CE}$ in the present study also could be explained by temperature differences that can limit the survival of the eggs [3]. In Ethiopia, the warmest period occurs from March to May, while the lowest annual minimum temperatures occur between the months of November and January creating a suitable condition for the lifecycle of the parasite [26]. This monthly variation also could be related to free roaming dogs infected with $E$. granulosus contaminating green pasture from June to September which corresponds to the rainy season in Ethiopia followed by infection and subsequent developments of cysts in the cattle host in the following months. Seasonal effect for the occurrence of CE has been reported for different animal species studied in Iran [27]. We note that this monthly variation should be interpreted with caution since the life cycle of the parasite involves two developmental stages: one in dogs and the other in ruminants.

Hydatidosis is a major zoonotic disease that has been reported in different food animals, dogs and humans in Ethiopia [3,6-13,15-19], and many other developing countries [2,27]. From the public health point of view it is one of the most neglected diseases. Apart from its public health impact, hydatidosis in food animals also causes substantial financial losses to the meat industry. In the present study we did not attempt to analyze the full economic loss as a result of organ condemnation due to hydatidosis. In addition to direct financial losses to the abattoirs in the domestic and export, markets hydatidosis can cause significant production losses through reduction in live body weight gain, milk yield, fertility rates and loss of valuable animal protein from edible offals [4,28].

\section{Conclusion and Recommendations}

In conclusion, bovine cysticercosis is a highly prevalent zoonotic disease that greatly varied by geographic origin and month of study causing substantial financial losses to the beef industry. The high prevalence of bovine $\mathrm{CE}$ should be a cause of concern to initiate nationwide control strategies to reduce human infections. Geographic and seasonal variations in the prevalence of the disease need to be further investigated at a national level to direct control measures towards high risk areas.

\section{Acknowledgement}

We appreciate the cooperation studied commercial abattoir and the support of the abattoir personnel for successes of this work.

\section{Competing Interest}

We declare that we have no any financial or personal interest that inappropriately influences writing his article.

\section{References}

1. Eckert J, Deplazes P (2004) Biological, epidemiological, and clinical aspects of echinococcosis, a zoonosis of increasing concern. Clin Microbiol Rev 17: 107-135.

2. McManus DP, Gray DJ, Zhang W, Yang Y (2012) Diagnosis, treatment, and management of echinococcosis. BMJ 344: e3866.

3. Otero-abad B, Torgerson PR (2013) A systematic review of the epidemiology of echinococcosis in domestic and wild animals. PLoS Negl Trop Dis 7: e2249.

4. Torgerson PR (2003) Economic effects of echinococcosis. Acta Trop 85: 113-118.

5. WHO/OIE (2014) WHO/OIE manual on echinococcosis in humans and animals: a public health problem of global concern. In: Eckert J, Gemmell MA, Meslin FX, Pawłowski ZS (eds.) World Organisation for Animal Health (Office International des Epizooties) and World Health Organization. World Organisation for Animal Health, Paris, France, 2001.

6. Jobre Y, Lobago F, Tiruneh R, Abebe G, Dorchies P (1996) Hydatidosis in three selected regions in Ethiopia : an assessment trial on its prevalence, economic and public health importance. Revue Med Vet 11: 797-804.

7. Koskei P, Janitschke K, Feseha G (2011) Prevalence of Echinococcus granulosus in some selected sites of Ethiopia. East Afr J Public Health 8: 170-175.

8. Bekele J, Butako B (2011) Occurrence and financial loss assessment of cystic echinococcosis (hydatidosis) in cattle slaughtered at Wolayita Sodo municipal abattoir, Southern Ethiopia. Trop Anim Health Prod 43: 221-228.

9. Berhe G (2009) Abattoir survey on cattle hydatidosis in Tigray Region of Ethiopia. Trop Anim Health Prod 41: 1347-1352.

10. Kebede N, Abuhay A, Tilahun G, Wossene A (2009) Financial loss estimation, prevalence and characterization of hydatidosis of cattle slaughtered at Debre Markos Municipality abattoir, Ethiopia. Trop Anim Health Prod 41: 1787-1789.

11. Kebede N, Mekonnen H, Wossene A, Tilahun G (2009) Hydatidosis of slaughtered cattle in Wolaita Sodo Abattoir, southern Ethiopia. Trop Anim Health Prod 41: 629-633.

12. Kebede N, Gebre-egziabher Z, Tilahun G, Wossene A (2011) Prevalence and financial effects of hydatidosis in cattle slaughtered in Birre-Sheleko 
Citation: Hiko A, Ibrahim H, Agga GE (2018) Abattoir Based Survey of Bovine Cystic Echinococcosis in Selected Commercial Abattoir in Ethiopia. J Vet Sci Technol 9: 527. doi:10.4172/2157-7579.1000527

Page 5 of 5

and Dangila Abattoirs, Northwestern Ethiopia. Zoonoses Public Health 58: 41-46.

13. Kebede W, Hagos A, Girma Z, Lobago F (2009) Echinococcosis/ hydatidosis: its prevalence, economic and public health significance in Tigray region, North Ethiopia. Trop Anim Health Prod 41: 865-871.

14. Negash K, Beyene D, Kumsa B (2013) Cystic echinococcosis in cattle slaughtered at Shashemanne Municipal Abattoir, south central Oromia Ethiopia: prevalence, cyst distribution and fertility. Trans R Soc Trop Med Hyg 107: 229-234.

15. Regassa F, Molla A, Bekele J (2010) Study on the prevalence of cystic hydatidosis and its economic significance in cattle slaughtered at Hawassa Municipal abattoir, Ethiopia. Trop Anim Health Prod 42: 977-984.

16. Tolosa T, Tigre W, Teka G, Dorny P (2009) Prevalence of bovine cysticercosis and hydatidosis in Jimma municipal abattoir, South West Ethiopia. Onderstepoort J Vet Res 76: 323-326.

17. Jibat T, Ejeta G, Asfaw Y, Wudie A (2008) Causes of abattoir condemnation in apparently healthy slaughtered sheep and goats at HELMEX abattoir, Debre Zeit, Ethiopia. Revue Méd Vét 159: 305-311.

18. Kebede N, Mitiku A, Tilahun G (2010) Retrospective survey of human hydatidosis in Bahir Dar, north-western Ethiopia. East Mediterr Health J 16: 937-941.

19. Klunqsovr P, Courtright P, Hendrikson TH (1993) Hydatid disease in the Hamar of Ethiopia: a public health problem for women. Trans R Soc Trop Med Hyg 87: 254-255.

20. Makuria T (1985) Human hydatidosis in Ethiopia. Ethiop Med J 23: 81-87.
21. Bizuwork A, Kebede N, Jibat T, Tilahun G, Kassa T (2013) Occurrences and financial significance of bovine cystic echincoccosis in Southern Wollo, Northeastern Ethiopia. J Vet Med Anim Health 5: 51-56.

22. Ogunrinade A, Ogunrinade BI (1980) Economic importance of bovine fasciolosis in Nigeria. Trop Anim Health Prod 12: 155-159.

23. Kebede N (2010) A retrospective survey of bovine hydatidosis in three abattoirs of Amhara National Regional State, northwestern Ethiopia. Trop Anim Health Prod 42: 323-325.

24. Getaw A, Beyene D, Ayana D, Megersa B, Abunna F (2010) Hydatidosis: prevalence and its economic importance in ruminants slaughtered at Adama municipal abattoir, Central Oromia, Ethiopia. Acta Trop 113: $221-225$.

25. Wachira TM, Macpherson CN, Gathuma JM (1991) Release and survival of Echinococcus eggs in different environments in Turkana, and their possible impact on the incidence of hydatidosis in man and livestock. J Helminthol 65: 55-61.

26. Lasage R, Seifu A, Hoogland M, Vries A (2014) Report on general characteristics of the Borana zone, Ethiopia. Institute for Environmental Studies, Report R-10/03, 18 November, 2010.

27. Daryani A, Alaei R, Arab R, Sharif M, Dehghan MH, et al. (2007) The prevalence, intensity and viability of hydatid cysts in slaughtered animals in the Ardabil province of Northwest Iran. J Helminthol 8: 13-17.

28. Budke CM, Jiamin Q, Qian W, Torgerson PR (2005) Economic effects of echinococcosis in a disease-endemic region of the Tibetan Plateau. Am J Trop Med Hygiene 73: 2-10. 